\title{
Primary Cutaneous B-Cell/T-Cell (Non- MF/SS) Lymphoma T2a TNM Finding v8
}

National Cancer Institute

\section{Source}

National Cancer Institute. Primary Cutaneous B-Cell/T-Cell (Non-MFISS) Lymphoma T2a

TNM Finding v8. NCI Thesaurus. Code C141387.

All disease encompassing in a less than 15-cm circular area. (from AJCC 8th Ed.) 